\title{
8
}
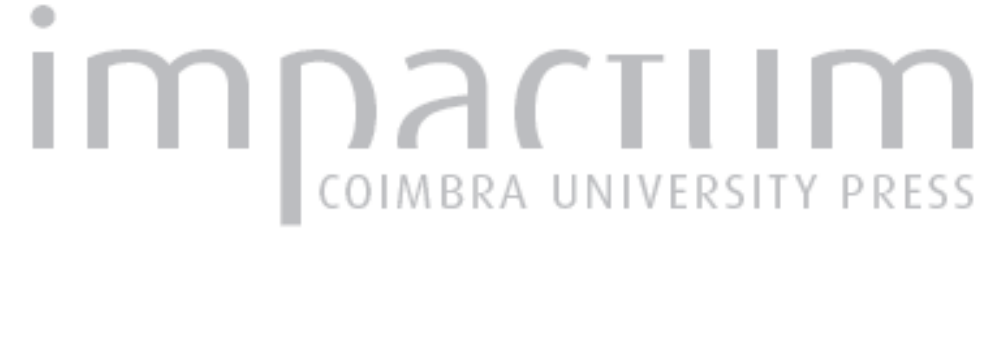

\section{Dignidade da pessoa humana: conceito fundamental da ciência jurídica}

\author{
Autor(es): $\quad$ Nogueira, Roberto Wagner Lima
}

Publicado por: Universidade Católica de Petrópolis

URL persistente:

URI:http://hdl.handle.net/10316.2/33900

DOI:

DOI:http://dx.doi.org/10.14195/2175-0947_1-1_2

Accessed : $\quad$ 26-Apr-2023 08:31:59

A navegação consulta e descarregamento dos títulos inseridos nas Bibliotecas Digitais UC Digitalis, UC Pombalina e UC Impactum, pressupõem a aceitação plena e sem reservas dos Termos e Condições de Uso destas Bibliotecas Digitais, disponíveis em https://digitalis.uc.pt/pt-pt/termos.

Conforme exposto nos referidos Termos e Condições de Uso, o descarregamento de títulos de acesso restrito requer uma licença válida de autorização devendo o utilizador aceder ao(s) documento(s) a partir de um endereço de IP da instituição detentora da supramencionada licença.

Ao utilizador é apenas permitido o descarregamento para uso pessoal, pelo que o emprego do(s) título(s) descarregado(s) para outro fim, designadamente comercial, carece de autorização do respetivo autor ou editor da obra.

Na medida em que todas as obras da UC Digitalis se encontram protegidas pelo Código do Direito de Autor e Direitos Conexos e demais legislação aplicável, toda a cópia, parcial ou total, deste documento, nos casos em que é legalmente admitida, deverá conter ou fazer-se acompanhar por este aviso.

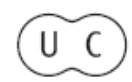



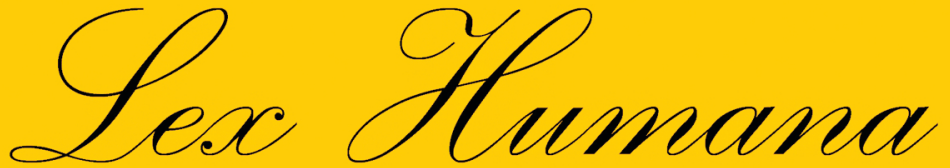

Revista do Programa de Pós-Graduação em Direito da UCP

ISSN(e) 2175-0947

Universidade Católica de Petrópolis Rua Benjamin Constant, 213 - Petrópolis - Centro CEP 25610-130

Tel: (24) 2244-4000 E-mail: lexhumana@ucp.br 
DIGNIDADE DA PESSOA HUMANA:

Conceito Fundamental da Ciência Jurídica

Roberto Wagner Lima Nogueira

"Fatos como os que ocorreram em Auschwitz são violentas advertências sobre o que pode acontecer quando os indivíduos - e por extensão, sociedades inteiras - perdem o contato com os sentimentos humanos básicos." Tenzi Gyatso, o décimo quarto Dalai Lama

\section{Considerações Iniciais}

É caro a todo operador do direito, o princípio jurídico posto no artigo $1^{\circ}$, inciso III, da Constituição Federal, qual, a dignidade da pessoa humana. Este escrito, faz deste conceito previsto no mundo do dever ser, uma ponte necessária e imprescindível para o estudo do ser do direito brasileiro no que pertine ao seu conceito fundamental.

2. A Dignidade da Pessoa Humana: como conhecê-la?

Começamos esta seção com uma reflexão propedêutica. Como podemos conhecer o significado do conceito jurídico dignidade da pessoa humana? É sabido que cada ser humano possui seu próprio universo de conhecimento, uma estrutura cultural que é o seu chamado: sistema de referência. Muitas vezes o sistema de referência de um ser humano, não pertence só a ele, pode tal sistema ser o universo cognitivo de uma coletividade. É natural, que oriundos das mesmas contingências, os sistemas de referências de pessoas ou de um mesmo grupo sejam semelhantes uns aos outros. ${ }^{1}$

Portanto, émediante o nosso sistema de referência que aproximaremos do objeto de estudo, daí porque tanto se fala que o conhecimento de uma realidade está sempre condicionado pelo sistema de referência do sujeito 1 Cf. TELLES JÚNIOR, Goffredo. $O$ direito quântico. 6 ed. São Paulo: Max Limonad. 1985, p. 284/285. Cf. também, NOGUEIRA, Roberto Wagner Lima, Fundamentos do Dever Tributário. Belo Horizonte: Del Rey. 2003. p. 8/11. 
conhecedor.

Neste sentido, poderíamos ponderar que o próprio modo de se aproximar do objeto eleito não é um ato de liberdade, liberdade aqui pensada como ausência de pré-motivo. Todo ato livre é sempre determinado por algum motivo, qual o patrimônio cultural do sujeito cognoscente, o confronto de uma informação vinda do mundo exterior, com todo o cabedal de aprendizado já armazenado pelo agente. ${ }^{2}$

Lado outro, o objeto a ser conhecido também está inserido em um sistema de referência, por exemplo, o conceito dignidade da pessoa humana está inserido dentro do sistema de referência que podemos chamar de, Direitos ocidentais, i.e, um conjunto de normas jurídicas, que culturalmente assentam sua especificidade na assimilação dos legados da Grécia e da Roma clássicas, do Cristianismo e da Igreja, das Revoluções liberais e dos prodígios da ciência e da técnica. ${ }^{3}$

Só a partir destas constatações, é que o leitor poderá entender a construção que se vai delineando neste texto. O sentido atribuído ao conceito dignidade da pessoa humana está marcado por um sistema de referência fruto dos direitos do ocidente, é impossível negar esta afirmação. Entretanto, a consagração do conceito só se afirmará no século XX, após a grande tragédia do Holocausto na $2^{\mathrm{a}}$ grande guerra, máxime a inesquecível lembrança do ocorrido nos campos de concentração nazista em Auschwitz.

Deste modo, não podemos negar o sistema de referência que circunda o objeto eleito, a dignidade da pessoa humana, como também não podemos negar a nossa visão de mundo, até porque interpretamos e lemos a realidade a partir de nós mesmos, razão pela qual somos concordes com Leonardo Boff quando ensina,

Ler significa reler e compreender, interpretar. Cada um lê com os olhos que tem. E interpreta a partir de onde os pés pisam. Todo ponto de vista é a vista de um ponto. Para entender como alguém lê, é necessário saber como são seus olhos e qual a sua visão de mundo. Isso faz da leitura sempre uma releitura. A cabeça pensa a partir de onde os

2 Cf. TELLES JÚNIOR, Goffredo, op. cit. p. 282/290.

3 Cf. JERÔNIMO, Patrícia. Os Direitos do Homem à escala das civilizações - Proposta de análise a partir do confronto dos modelos ocidental e islâmico. Coimbra: Almedina. 2001. p. 187. 
pés pisam. Para compreender, é essencial conhecer o lugar de quem olha. Vale dizer: como alguém vive, com quem convive, que experiências tem, em que trabalha, que desejos alimenta, como assume os dramas da vida e da morte e que esperanças o animam. Isso faz da compreensão sempre uma interpretação. Sendo assim, fica evidente que cada leitor é co-autor. Porque cada um lê e relê com os olhos que tem. Porque compreende e interpreta a partir do mundo que habita. ${ }^{4}$

\section{Sobre o conceito jurídico fundamental e sua natureza}

Fixadas nossas premissas para conhecimento de nosso tema, qual, a dignidade da pessoa humana, consoante art. $1^{\circ}$, inciso III, da Constituição Federal, passamos a defini-lo com um conceito jurídico fundamental para o ordenamento brasileiro, bem como ao final discorreremos sobre sua natureza jurídica.

Conceituar é abstrair, é retrooperar até as origens do pensamento em busca do sentido do conceito construído. É como salienta Lourival Vilanova, "O conceito, desta sorte, é uma abstração; o pensamento, por essência, se move no abstrato. Não abstrato na acepção do hipotético, irreal, mas no sentido de que separa o que existe unido, decompõe o que se apresenta em indissolúvel unidade." 5

Sigamos margeando livremente o pensamento do mestre Vilanova. O conceito supremo ou fundamental da cada sistema científico funciona logicamente como um pressuposto do conhecimento. No direito, efetivamente, é ele - conceito fundamental - que delimita dentro do campo do social, a dignidade da pessoa humana como pressuposto da ciência jurídica. Neste sentido, o conceito fundamental da dignidade da pessoa humana tem a função lógica de um a priori. É, com efeito, um esquema prévio, um princípio fundante, um ponto de vista anterior, munido do qual o pensamento se dirige à realidade jurídica, desprezando seus vários setores, fixando aquele que corresponde às linhas ideais delineadas ainda que inicialmente pelo conceito $4 \quad$ Cf. Águia e a galinha: uma metáfora da condição humana. $24^{\mathrm{a}} \mathrm{ed}$. Petrópolis: Vozes. 1998, p. 9.

$5 \quad$ Sobre o Conceito de Direito. Escritos Jurídicos e Filosóficos. V. 1. São Paulo: AXIS MVNDI-IBET. 2003, p. 14. 
fundamental. ${ }^{6}$

Sem conceito fundamental, é de se indagar como a história, a sociologia, a biologia e o direito podem extrair do real os seus objetos específicos? Não poderiam. Ouçamos Vilanova:

Para se investigar onde se encontra o direito, fato social e o fenômeno biológico ou histórico, é necessária a constituição prévia de um conceito supremo para cada setor. Supremo ou fundamental, porquanto não é obtido, nem se deixa reduzir a outros conceitos. E é anterior à experiência, uma vez que sem a prévia determinação do conceito, não seria possível o conhecimento. O pensamento perder-se-ia na selva extraordinariamente intricada de fatos diversos que compõem o real, sem aptidão para discernir estes fatos em categorias específicas. O conceito fundamental para cada ciência, é, portanto, a condição de experiência. E, na qualidade de condição, tem de ser a priori. A aprioridade do conceito fundamental nada mais representa do que um dos aspectos das condições transcendentais do conhecimento, postas em relevo pela filosofia kantiana. ${ }^{7}$

A dignidade da pessoa humana muito embora positivada no texto constitucional, o que à primeira vista parece contrariar o que acima foi dito, sobretudo no que concerne ao a priori do conceito fundamental, é conceito fundamental que antecede ao próprio texto constitucional, é um a priori lógico que condiciona toda experiência hermenêutica interpretativa do art. $1^{\circ}$, III, da Carta Magna. Lembremos de algumas notas essenciais do pensamento de Locke, o direito surge no espaço aberto pela liberdade, à liberdade se autolimita em nome da dignidade da pessoa humana. Nasce assim, o Estado. O Estado se fundamenta na defesa deste valor fundamental, e só se legitima se diuturnamente estiver compromissado com este valor supremo: a dignidade da pessoa humana.

Nesta perspectiva também se direciona o pensamento de Ingo Wolfang

6 Cf. noutro contexto VILANOVA, Lourival, op. cit. 17.

7 Cf. VILANOVA, Lourival, op. cit. p. 17. 
Sarlet, ao dizer que, "Assim, vale lembrar que a dignidade evidentemente não existe apenas onde é reconhecida pelo Direito e na medida que este a reconhece, já que constitui dado prévio, no sentido de preexistente e anterior a toda experiência especulativa."

O conceito jurídico dignidade da pessoa humana, (que acima de tudo é um conceito inaugurador de sentido), é o conceito fundamental da ciência jurídica. Na ordem do conhecimento jurídico é o conceito supremo. Não é possível, logicamente, remontar a um conceito mais alto no domínio do jurídico. Nesse particular domínio, ele é único. Por ser o conceito supremo não está coordenado a outros, nem é derivado de outros. Por seu posto lógico, é o vértice da pirâmide jurídica conceitual. Sua amplitude de validez e legitimidade cobre todo o campo dos objetos jurídicos.

Para Radbruch ${ }^{9}$, citado por Celso Lafer, há princípios fundamentais de Direito que são mais fortes do que todo e qualquer preceito jurídico positivo, de tal modo que toda lei que os contrarie não poderá deixar de ser privada de validade. Eis aí, mais uma vez, o chamamento da dignidade da pessoa humana, como postulado normativo supremo no direito brasileiro.

Não obstante o direito posto, enquanto objeto da ciência do direito, possa ser dividido didaticamente em ramos, o que fornece unidade e sentido às investigações científicas sobre o direito, é o conceito de dignidade da pessoa humano previsto no art. $1^{\circ}$, III da Constituição Federal. Este conceito fundamental funciona logicamente, como o pressuposto unificador de todos os ramos científicos do direito.

Ainda, fortes em Lourival Vilanova, podemos afirmar que o direito é, essencialmente, um esforço humano no sentido de realizar o valor justiça. Essa dimensão ideal existe no conceito fundamental da dignidade da pessoa humana. Pois este conceito não se reduz a uma mera forma de sugestionar atos, com total indiferença para o valor. ${ }^{10}$ Se o conceito dignidade da pessoa humana é dever ser, e o é; é dever ser de algo. Este algo é a busca incessante da proteção jurídica ao ser humano, busca esta que impregna o conceito fundamental dignidade da pessoa humana por corolário todo o ordenamento $8 \quad$ Dignidade da Pessoa Humana e Direitos Fundamentais na Constituição Federal de 1988. $4^{\text {a }}$ ed. rev. e atualizada. Porto Alegre: Livraria do Advogado. 2006, p. 42.

9 Apud. LAFER, Celso. A Reconstrução dos Direitos Humanos: um diálogo com o pensamento deHanna Aredent. São Paulo: Cia das Letras, 1988. p. 78.

10 Cf. VILANOVA, Lourival, op. cit. p. 50 
jurídico.

O conceito dignidade da pessoa humana há que se realizar no mundo do ser, afinal, salienta Vilanova, as normas jurídicas não constituem "direito" se carecem de toda relação com a realidade social humana. ${ }^{11}$

Já é hora de acrescentarmos mais uma questão ao debate. Vejamos.

Qual é a natureza jurídica do conceito fundamental, dignidade da pessoa humana? Trata-se de um princípio jurídico? É uma regra? A distinção entre princípios e regras assumiu importância capital em vários planos do cenário jurídico nacional e internacional.

A sistematização dada ao tema, princípio jurídico e regras, como espécies de normas, tem em Ronald Dworkin, seu grande divulgador. Por todos, ouçamos as palavras do Professor Luis Roberto Barroso,

A distinção qualitativa entre regra e princípio é um dos pilares da moderna dogmática constitucional, indispensável para superação do positivismo legalista, onde as normas se cingiam a regras jurídicas. A Constituição passa a ser encarada como um sistema aberto de princípios e regras, permeável a valores jurídicos suprapositivos, no qual as idéias de justiça e de realização dos direitos fundamentais desempenham um papel fundamental. ${ }^{12}$

Como bem anotou Ana Paula de Barcellos com sutileza, "Não é preciso descrever aqui todas a discussões teóricas envolvendo a distinção entre regras e princípios e nem seria útil reproduzir os vários critérios que têm sido empregados para extremar as duas espécies normativas", para quem o quiser, remetemos o leitor ao texto da Professora Barcellos ora citado. ${ }^{13}$

Cf. VILANOVA, Lourival, op. cit. p. 60.

12 Fundamentos Teóricos e Filosóficos do Novo Direito Constitucional Brasileiro. (Pós-modernidade, teoria crítica e pós-positivismo). In BARROSO, Luís Roberto (org.). A Nova interpretação Constitucional. Ponderação, Direitos Fundamentais e Relações Privadas. 2 ed. Rio de Janeiro: Renovar. 2006, p. 30. 13 Alguns parâmetros normativos para a ponderação constitucional. BARROSO, Luís Roberto (org.). A Nova interpretação Constitucional. Ponderação, Direitos Fundamentais e Relações Privadas. 2 ed. Rio de Janeiro: Renovar. 2006. p. 70/71. 
Enfim, para respondermos a indagação acima posta, qual a natureza do conceito dignidade da pessoa humana, vamos nos valer dos ensinamentos de Humberto Ávila.

Para este autor, crítico da classificação proposta por Dworkin, pode-se diferençar os princípios das regras baseado em três argumentos: a)natureza da descrição/comportamento - as regras descrevem comportamentos ou poderes para atingir fins; princípios descrevem fins cuja realização depende de efeitos decorrentes da adoção de comportamentos; b)- natureza da justificação exigida - as regras exigem um exame de correspondência entre o conceito da norma e o conceito de fato, sempre com a verificação da manutenção ou realização das finalidades sub- e sobrejacentes; os princípios exigem uma compatibilidade entre os efeitos da conduta e a realização gradual do fim; c)- natureza da contribuição para decisão - as regras têm pretensão terminativa, e os princípios têm pretensão complementar. ${ }^{14}$

A sistematização proposta por Humberto Ávila, torna-se sobremais importante quando cria uma terceira categoria de normas, que não se confunde nem com os princípios nem com as regras, são os chamados postulados normativos, que se caracterizam por serem normas de segundo grau que estruturam a aplicação de outras normas. O autor cita como exemplo de postulados normativos, a proporcionalidade e a razoabilidade, chamados de princípios pela doutrina tradicional.

Pois bem. Para nós a natureza jurídica do conceito fundamental - dignidade da pessoa humana, insculpida no art. $1^{\circ}$, III, da Constituição Federal - é a de um postulado normativo, muito embora tal conceito estar inserido no título I, Dos Princípios Fundamentais. Atecnias da linguagem objeto, que não interferem na linguagem científica. Insista-se, o postulado normativo da dignidade da pessoa humana se diferencia das regras e princípios quanto ao nível e função. Enquanto os princípios e as regras são os objetos da aplicação, o postulado normativo da dignidade da pessoa humana estabelece os critérios de aplicação dos princípios e das regras. E, enquanto os princípios e as regras servem de comandos para determinar condutas obrigatórias, permitidas e proibidas, ou condutas cuja adoção seja necessária para atingir fins, o postulado normativo da dignidade de pessoa humana serve como parâmetro para a realização de outras normas.

Por ser um conceito jurídico fundamental, o postulado normativo da dignidade da pessoa humana é uma metanorma, que estrutura a aplicação de 14 Princípios e Regras e a Segurança Jurídica. Revista de Direito do Estado - RDE. Rio de Janeiro: Renovar. $\mathrm{n}^{\mathrm{o}}$ 1, janeiro/março de 2006. p. 194/915. 
outras normas, com elas não se confundindo, por isso concordamos com a oportuna nomenclatura proposta por Humberto Ávila. ${ }^{15}$

4. Apontamentos sobre os modelos jurídicos, ocidental e islâmico

Nos itens anteriores, anotamos ainda que de passagem, a especificidade da construção de sentido do conceito dignidade da pessoa humana no interior dos direitos ocidentais, agora faremos uma sucinta aproximação ao modelo jurídico islâmico.

Como bem pontuado por Ana Paula de Barcellos ${ }^{16}$, a dignidade da pessoa humana está marcada no ocidente, por quatro momentos fundamentais, a saber: o Cristianismo, o iluminismo-humanista, a obra de Kant e o refluxo da Segunda Grande Guerra Mundial, nessa ordem.

Vejamos o modelo islâmico. O Islão é submissão a Deus. É esse o seu significado etimológico e também o seu sentido mais profundo. Se podemos falar de uma civilização, falaremos ainda com mais propriedade de uma comunidade de fiéis. ${ }^{17}$

O Alcorão é um código, ainda que nem todas suas disposições possam integrar a categoria de normas jurídicas, porque essencialmente um livro de princípios religiosos e morais, temos de convir que há no Alcorão matéria jurídica. A relação primordial a ordenar no Alcorão é a que une os homens entre si, mas sobretudo a que une os fiéis a Deus.

O direito no Islão está marcado por esta submissão a Deus. Diremos, por isso, que a cada identidade civilizatória corresponde uma identidade jurídica. Negar isto, é sobremaneira difícil.

É como adverte Patrícia Jerônimo,

O Direito não é universal. Universal é a necessidade humanamente sentida de viver de acordo com uma ordem de valores e de normas, não a forma por que essa necessidade ganha concreta

15 Cf. ÁVILA, Humberto. Teoria dos Princípios. da definição à aplicação dos princípios jurídicos. $2^{\mathrm{a}}$ ed. São Paulo: Malheiros. 2003. p. 79/116.

16 A Eficácia Jurídica dos Princípios Constitucionais. O Princípio da Dignidade da Pessoa Humana. Rio de Janeiro: Renovar. 2002. 103/104. 17 Cf. JERÔNIMO, Patrícia. Os Direitos do Homem à escala das Civilizações. Proposta de análise do confronto dos Modelos Ocidental e Islâmico. op. cit. p. 107-108. 
realização. Pretender que o Direito pode assumir uma forma única, independente da realidade que intenta ordenar, significa uma inadmissível distorção dos termos da equação que preside às relações entre o jurídico e o humano. Significaria sempre uma pretensão ilegítima - quer porque simplesmente defasada, quer porque as mais das vezes comprometida com projectos de natureza extrajurídica, muito distantes de qualquer ideal de uniformização do justo; dirigidos, acima de tudo, à maximização do domínio. ${ }^{18}$

A professora portuguesa se filia àquela corrente para a qual o direitos humanos devem ser vistos no conjunto como um Direito Natural civilizacional relativo, ou seja, um Direito Natural não no sentido de universal que deriva da natureza do homem e das coisas, mas um Direito que mais modestamente, se contenta com o ser a expressão do "justo" válida para um concreta comunidade humana.

Se o individualismo é o humanismo possível para os espíritos ocidentais, para os muçulmanos prevalece o coletivo, os muçulmanos não se concebem isoladamente, mas como parte de uma comunidade religiosa, por isso, tal como o mundo a que se dirige, o Direito muçulmano é um Direito religioso, logo, esse caráter absoluto lhe permite uma extensão virtualmente ilimitada, muito além das fronteiras que um ocidental fixaria para os domínios do Direito. Por estas e por outras, é que os conceitos de dignidade da pessoa humana e direitos humanos são construções típicas do ocidente.

Sobre a concepção dos direitos humanos como tema global, debatem duas teorias, os relativistas e os universalistas.

Para os primeiros (relativistas ou culturalistas), a dignidade da pessoa humana - sendo um valor que pode dizer-se universal - conhece formas muito diversas de expressão. Tantas quantas as formas de ser Homem, porque o ser humano é um ser acima de tudo situado (culturalismo). A natureza humana não se realiza numa comunidade abstrata, o homem realiza a sua natureza no seio das culturas. Fora dos domínios ocidentais a dignidade ínsita na natureza humana ganha formas diferentes, não significa necessariamente o reconhecimento aos indivíduos de direitos oponíveis ao poder e aos outros; passa, muitas vezes, por coisas como a honra, sentimento de pertença à 18 Cf. Os Direitos do Homem... op. cit. p. 183. 
comunidade, devoção religiosa, gestos de generosidade e deveres perante o grupo.

Em respeito às diferenças civilizatórias, não está - segundo esta corrente - o ocidente autorizado a julgar outras culturas. Noutro dizer, levado as últimas conseqüências o relativismo há que admitir que tolera a intolerância.

Já os segundos (universalistas), estão estruturados sobre o conceito de dignidade da pessoa humana. A unidade do gênero humano sobrepõese, então, à diversidade das culturas habitadas pelo homem. Existe, contra todas as dúvidas dos culturalistas, uma identidade humana universal. E é por referência a ela - bem como à irredutível dignidade da pessoa humana que ela leva implicada - que se justificam os Direitos do Homem com a sua característica de universalidade. ${ }^{19}$

Mais difícil do que situar os autores em uma corrente ou outra, é fixar para ambas as correntes o significado preciso do que se entende por dignidade da pessoa humana. Vejamos doravante.

Consoante lições de Ingo Wolfgang Sarlet, os Estados Unidos da América, a maior potência do mundo, membro da ONU (Organização das Nações Unidas), em números expressivos de estados federados admite a execução da pena capital, pena de morte. E a sua Suprema Corte, embora não de forma unânime, entende-a constitucional. Entretanto, a Suprema Corte norte-americana, tem decidido que determinadas técnicas de executar a pena capital, são cruéis e desumanas, logo devem ser proibidas. É exemplo, a morte por enforcamento, que constitui no entender da Corte, prática atentatória à dignidade da pessoa humana, nomeadamente, por infligir - ao menos em relação aos outros meios utilizados (letal e eletrocutamento) sofrimento desnecessário ao sentenciado, já que constatada a possibilidade maior de uma postergação do estado de inconsciência e morte, com risco de asfixia lenta e até mesmo de decapitação parcial ou total, verificada em diversos casos. ${ }^{20}$

Veja caro leitor, os EUA entendem que a pena de morte não é ofensiva à dignidade da pessoa humana, apenas o modo de executá-la, que pode vir a ser ofensivo à dignidade da pessoa humana.

No Islão, a Constituição Iraniana de 1980, em seu artigo 22, dispõe que, "a dignidade dos indivíduos é inviolável [...] salvo nos casos autorizados por lei”. Vejamo quão frágil também o é a proteção da dignidade da pessoa 19 Cf. JERÔNIMO, Patrícia, op. cit. p. 246/256.

20 Cf. SARLET, Ingo Wolfgang, op.cit. p. 56. 
humana neste país, onde ainda se verificam práticas de tortura, mutilações genitais, discriminação religiosa e sexual. ${ }^{21}$

Como membro da delegação brasileira junto a CDH (Comissão de Direitos Humanos) da ONU, J.A. Lindgren Alves ${ }^{22}$, destaca a preocupação da $\mathrm{CDH}$ com a situação dos direitos humanos no Sudão. Em situação avaliada pela CDH no anos de 1991 a 1994, apurou-se que o sistema penal sudanês contém dois componentes principais, que são radicalmente contrários às provisões das convenções internacionais de que o Sudão é parte. Quais sejam, crimes absolutos e a instituição de retribuição.

Explicando. Os crimes absolutos são imperdoáveis e passíveis de punição corporal ou pena de morte, não contemplando atenuações de responsabilidade baseadas em gênero ou idade, inclusive, a partir da puberdade, havendo completado quinze anos, e até os 70 , todos os ofensores são punidos, podendo as crianças entre sete anos e a puberdade ter a sentença transformada pelas Cortes em açoitamento que não excederá vinte chibatadas. 23

São espécies de crimes absolutos, o assalto à mão armada (punível com morte, ou crucificação e morte ou amputação da mão direita e do pé esquerdo); roubo capital (punido pela amputação da mão direita; adultério feminino (punido com morte por apedrejamento se a ré for casada, ou 100 chibatadas, se solteira); adultério masculino (punição com açoitamento, e, adicionalmente, com expatriação por um ano). ${ }^{24}$

A retribuição múltipla, segundo componente do sistema penal questionado pela $\mathrm{CDH}$, também está prevista no Código Penal e consiste na possibilidade de um indivíduo ser executado em lugar de um grupo e um grupo no lugar de um indivíduo. ${ }^{25}$

Em respostas aos questionamentos da Comissão de Direitos Humanos $(\mathrm{CDH})$ da ONU, o governo sudanês alegou que algumas dessas práticas do direito islâmico estão enraizadas nas tradições do país. Todavia, ainda que isto seja realmente a realidade do direito sudanês, a verdade é que o Sudão ratificou o Pacto Internacional de Direitos Civis e Políticos e a Convenção

21 Cf. SARLET, Ingo Wolfgang. op. cit. p. 56, nota de rodapé no 110.

22 Os Direitos Humanos como tema global. São Paulo: Perspectiva. 1994, p. $142 / 143$

23 Cf. ALVES, J.A. Lindgren, op. cit. p. 142

24 Cf. ALVES, J.A. Lindgren, op. cit. p. 143.

25 Cf. ALVES, J.A. Lindgren, op. cit. p. 143 
sobre os Direitos da Criança. ${ }^{26}$

Para finalizar, oportunas são as palavras do embaixador brasileiro, J.A. Lindgren Alves, quando em seu livro aborda o tema da Universalidade dos Direitos Humanos, e não deixa de ponderar,

Do ponto de vista da diplomacia e do direito, o avanço é extraordinário. Apesar disso, porém, não se pode afirmar que, no campo operativo, o universalismo tenha realmente suplantado o relativismo. ${ }^{27}$

5. Por que a pessoa humana possui dignidade?

Dentre tantas, podemos pelo menos detectar duas questões centrais que envolvem a indagação supra: o ser humano e sua dignidade.

O objetivo principal da filosofia ao longo dos séculos, sempre foi praticamente um, qual, conhecer o homem. São de $\mathrm{Kant}^{28}$ as famosas indagações: $1^{\mathrm{a}}$ ) $\mathrm{O}$ que eu posso saber? $2^{\mathrm{a}}$ ) $\mathrm{O}$ que eu devo fazer? $3^{\mathrm{a}}$ ) $\mathrm{O}$ que eu posso esperar? $4^{a}$ ) O que é o homem?

A primeira pergunta diz respeito à metafísica, a segunda à moral, a terceira à religião. A bem da verdade as três primeiras, podem ser resumidas na última, a quarta, pois tudo se fundamenta no homem.

O que se entende por dignidade enquanto atributo do homem? Segundo o Dicionário de Filosofia de Nicola Abbagnano ${ }^{29}$, por princípio da dignidade da pessoa humana, entende-se a exigência enunciada por Kant consoante a fórmula do imperativo categórico: "Age de tal forma que trates a humanidade, tanto na tua pessoa como na pessoa de qualquer outro, sempre também como um fim e nunca unicamente como um meio”. Significando que para Kant, as coisas têm preço, são substituíveis, relativas; o homem tem dignidade, por isso não tem preço, é um valor absoluto e insubstituível.

Etimologicamente, dignidade vem do latim digna, merecedora de alguma coisa digna, significando também cargo, honra ou honraria. É adjetivo derivado da forma verbal decet, de decere, convir. De onde emanam também os significados para decente, de que é sinônimo. ${ }^{30}$

26 Cf. . ALVES, J.A. Lindgren, op. cit. p. 143.

27 Cf. . ALVES, J.A. Lindgren, op. cit. p. 139/140.

28 Apud. MONDIN, Battista. Definição Filosófica da Pessoa Humana.

Bauru: EDUSC. 1998. p. 7.

29 Dicionário de Filosofia Nicola Abbagnano. São Paulo: Martins Fontes. 1998. p. 276.

30 SILVA, Deonísio da. De onde vêm as palavras - origens e curiosidades 
Lança luzes sobre a idéia da dignidade da pessoa humana, a Ministra do Supremo Tribunal Federal, Dr $^{\mathrm{a}}$ Carmem Lúcia Antunes Rocha, quando pontifica que,

Dignidade é o pressuposto da idéia de justiça humana, porque ela é que dita a condição superior do homem como ser de razão e sentimento. Por isso é que a dignidade humana independe de merecimento pessoal ou social. Não se há de ser mister ter de fazer por merecê-la, pois ela é inerente à vida e, nessa contingência, é um direito pré-estatal.

O sistema normativo de direito não constitui, pois, por óbvio, a dignidade da pessoa humana. O que ele pode é tão-somente reconhecê-la como dado essencial da construção jurídico-normativa, princípio do ordenamento e matriz de toda organização social, protegendo o homem e criando garantias institucionais postas à disposição das pessoas a fim de que elas possam garantir a sua eficácia e o respeito à sua estatuição. A dignidade é mais um dado jurídico que uma construção acabada no direito, porque firma e se afirma no sentimento de justiça que domina o pensamento e a busca de cada povo em sua busca de realizar as suas vocações e necessidades. ${ }^{31}$

Ingo Wolfgang Sarlet, conceitua a dignidade da pessoa humana como,

a qualidade intrínseca e distintiva reconhecida em cada ser humano que o faz merecedor do mesmo respeito e consideração por parte do Estado e

da língua portuguesa. 14ª ed. São Paulo: A Girafa. 2004. p. 264.

31 O Princípio da Dignidade da Pessoa Humana e a Exclusão Social. Revista Interesse Público. Ano 1. nº 4, outubro/dezembro de 1999. São Paulo: Notadez. p. 26. 
da comunidade, implicando, neste sentido, um complexo de direitos e deveres fundamentais que assegurem a pessoa tanto contra todo e qualquer ato de cunho degradante e desumano, como venham a lhe garantir as condições existenciais mínimas para uma vida saudável, além de propiciar e promover sua participação ativa e co-responsável nos destinos da própria existência e da vida em comunhão com os demais seres humanos. ${ }^{32}$

Diante do que já vimos, impera afirmar que o homem é um ser de valor absoluto, por isto um ser dotado de uma dignidade que lhe é imanente, e sem a qual o sentido de justiça humana se esvai.

Assim sendo, já podemos tentar responder a questão que abre este tópico, por que o ser humano possui dignidade? Sigamos. É preciso ir à fonte, que é o próprio homem, porquanto a dignidade é atributo seu. Lado outro, poderíamos analisar o homem sob vários pontos de vista, do ponto de vista da natureza, do ponto de vista religioso, do ponto de vista psicológico, do ponto de vista filosófico, enfim, de várias maneiras.

Numa tomada de posição, vamos tentar responder a provocação que inaugura este tópico, olhando a pessoa humana sob algumas perspectivas jurídico-filosóficas, porquanto toda idéia será reconduzida à base empírica do Texto Constitucional. $1^{\text {a }}$ resposta) a pessoa humana possui dignidade porque ela é espírito; $2^{\mathrm{a}}$ resposta) porque o ser humano é pessoa. Vejamos as duas.

\subsection{Porque a pessoa humana é espírito}

Que o homem seja espírito não é coisa óbvia. O que é óbvio é exatamente o contrário: que o homem é matéria, corpo. Esta é a advertência sábia de Battista Mondin. ${ }^{33}$

O homem em sua espiritualidade é um ser livre, sobreleva-se além dos limites de espaço e de tempo que o circundam. Avalia e julga o mundo todo da experiência, tanto o passado quanto o presente, podendo ainda prefigurar o seu futuro. O homem em sua condição espiritual é chamado a voltar-se sempre para uma realidade que o transcende. Fruto desta transcendência é a

Dignidade da Pessoa Humana... op. cit. p. 60.

33 Cf. Definição Filosófica da Pessoa Humana. op. cit. p. 21. 
sua dignidade e superioridade diante do resto da criação ${ }^{34}$. O homem possui uma razão que o permite sentir que a sua condição de matéria não é a sua essência mais íntima: que existe nele um ser mais profundo, que se chama, sopro vital, espírito, alma ou mente.

O exemplar melhor acabado da espiritualidade do homem é a sua liberdade. Liberdade é condição própria do espírito. Mesmo preso em uma penitenciária, espiritualmente o homem continua livre. O espírito, e somente o espírito, é essencialmente livre. O espírito sopra onde quer. Lembremos do filme ganhador do Oscar, A Vida é Bela, onde mesmo estando ambos em um campo de concentração no período nazista, o pai pintava para o filho as cores da espiritualidade humana.

Em razão desta espiritualidade humana, sábias foram as palavras dos representantes do povo brasileiro, reunidos em Assembléia Nacional Constituinte, quando positivaram no preâmbulo da Constituição da República Federativa do Brasil, “[...] promulgamos, sob a proteção de Deus, a seguinte Constituição da República Federativa do Brasil.

É sabido que o preâmbulo contém uma proclamação de princípios para o ordenamento que acaba de se implantar. O preâmbulo é sim um decisivo elemento de interpretação e integração dos diversos artigos que the seguem. É o que nos ensina Alexandre de Moraes ${ }^{35}$,

Apesar de não fazer parte do texto constitucional propriamente dito e, conseqüentemente não conter normas constitucionais de valor jurídico autônomo, o preâmbulo não é juridicamente irrelevante, uma vez que deve ser observado como elemento de interpretação e integração dos diversos artigos que lhe seguem.

Veja caro leitor, o preâmbulo não é despiciendo para o operador do direito, porquanto o seu valor de elemento de interpretação e integração adere a outros artigos e enunciados da Constituição para que assim sejam aplicados fielmente os valores protegidos pelo povo brasileiro.

Portanto, o enquanto elemento de integração e interpretação 34 JOÃO PAULO II. Carta Encíclica Fides et Ratio. Aos Bispos da Igreja Católica sobre as relações entre a Fé e a Razão. $7^{\mathrm{a}}$ ed. São Paulo: Paulinas. 2004, p. 82 
não autônomo, na dicção acertada de Alexandre Moraes, o preâmbulo é instrumento decisivo para o alcance do significado da dignidade da pessoa humana, positivado art. $1^{\circ}$, III da Carta Magna. Ou, no dizer de Juan Bautista Alberdi, o preâmbulo serve de fonte interpretativa para dissipar as obscuridades das questões práticas e de rumo para atividade política do governo. ${ }^{36}$

Entendido o preâmbulo como fonte interpretativa das normas constitucionais, já podemos afirmar sem qualquer receio de erro, que a Constituição Federal reconhece que a dignidade da pessoa humana está fundada na existência de Deus. É um nítido reconhecimento Constitucional da natureza espiritual do homem.

Atenção caro e dileto leitor. Não está aqui afirmação de que o Estado brasileiro adota esta ou aquela religião, não seríamos ingênuos a tanto. O que se está a dizer, porque juridicamente possível, é que para nossa Constituição o homem possui dignidade como pessoa humana por que fundado em Deus. É a leitura que se deve fazer do preâmbulo em conexão com o art. $1^{\circ}$, III, da Carta Maior.

No Brasil, existe a separação entre o Estado e a Igreja, sendo assim o Brasil é um país leigo, laico ou não-confessional como bem anota Pedro Lenza. ${ }^{37}$

Inclusive, consoante art. 5\%, VI, “é inviolável a liberdade de consciência e de crença, sendo assegurado o livre exercício dos cultos religiosos e garantida, na forma da lei, a proteção aos locais de culto e suas liturgias".

Agora, vamos aos esclarecimentos. O Estado é laico, não tem religião, porém, o cidadão e seus direitos estão sob a proteção de Deus, por força da norma interpretativa oriunda do preâmbulo, o que implica a dizer que a Constituição brasileira delineia de forma límpida, a distinção entre espiritualidade e religião.

A Constituição reconhece a espiritualidade do homem, porque invoca a proteção de Dues no preâmbulo. De qual Deus? Claro fica que é o Deus da espiritualidade, o Deus que transcende e agasalha todas as pessoas humanas independentemente do seu credo religioso. O Deus da Constituição da República Federativa do Brasil é o DEUS até mesmo do ateu, do agnóstico, porque é um Deus de pura espiritualidade, fruto da transcendência humana, 36 Apud. MORAES, Alexandre de. op. cit. p. 15.

37 Direito Constitucional Esquematizado. 10 ed. São Paulo: Método. 2006.

p. 62 . 
que ultrapassa os limites estreitos seja do catolicismo, do islamismo, do budismo, do judaísmo, do hinduísmo, ou de qualquer outra religião.

Vejamos agora a distinção entre religião - que é vedado ao Estado brasileiro aderir a uma - e espiritualidade, conceito agasalhado pela Constituição Federal.

A religião objetiva estabelecer princípios éticos e morais básicos, porém, pode-se falar de ética e moralidade sem ter de se recorrer à religião, valendo-se assim do conceito de espiritualidade. Quem nos vai esclarecer a diferença entre a religião e a espiritualidade (conceito constitucionalmente protegido), é o Dalai Lama ${ }^{38}$, ouçam,

Na realidade, creio que há uma importante distinção a ser feita entre religião e espiritualidade. Julgo que a religião esteja relacionada com a crença no direito à salvação pregada por qualquer tradição de fé, crença esta que tem como um de seus principais aspectos a aceitação de alguma forma de realidade metafísica ou sobrenatural, incluindo possivelmente uma idéia de paraíso ou nirvana. Associados a isso estão os ensinamentos ou dogmas religiosos, rituais, orações, e assim por diante. Considero que a espiritualidade esteja relacionada com aquelas qualidades do espírito humano - tais como amor e compaixão, paciência, tolerância, capacidade de perdoar, contentamento, noção de responsabilidade, noção de harmonia - que trazem felicidade tanto para a própria pessoa quanto para os outros. Ritual e oração, junto com as questões de nirvana e salvação, estão diretamente ligados à fé religiosa, mas essas qualidades interiores não precisam estar. Não existe portanto nenhuma razão pela qual um indivíduo não possa desenvolvê-las, até mesmo em alto grau, sem recorrer a qualquer sistema religioso ou metafísico. É por isso que às vezes digo que talvez se possa dispensar a religião. O que não se pode dispensar são essas qualidades 38 DALAI LAMA. Sua Santidade o Dalai Lama. Um Ética para o Novo Milênio. $7^{\mathrm{a}}$ ed. Rio de Janeiro: Sextante. 1999. p. 32/33. 
espirituais básicas.

Insistamos neste particular, o postulado normativo da dignidade da pessoa humana, previsto no art. $1^{\circ}$, inciso III da Constituição Federal, deve ser interpretado e conhecido e justificado à luz da experiência espiritual de Deus, contemplada no preâmbulo da Carta Magna, e fonte interpretativa do direito constitucional conforme já vimos de ver.

É importante esta distinção entre espiritualidade e religião, não se trata de uma separação entre uma e outra, tão-somente uma distinção. Uma vez distintas, podem relacionar e conviver, mas sem que uma dependa necessariamente da outra. É pensando assim que podemos conceituar juridicamente a idéia de espiritualidade (preâmbulo da Constituição) como idéia fundante do conceito de dignidade da pessoa humana.

Sem o sentido de espiritualidade presente em nós, não podemos sacar do Texto Constitucional, o exato sentido da dignidade da pessoa humana. Espiritualidade tem a ver com experiência, não com doutrina, não com dogmas, não com ritos, não com celebrações, que são caminhos institucionais capazes de nos ajudar na espiritualidade, mas que são posteriores a espiritualidade.

É como ensina Leonardo Boff ${ }^{39}$, ouçam, "Nasceram da espiritualidade, podem conter espiritualidade, mas não são a espiritualidade. São água canalizada, não a fonte da água cristalina"

A experiência de Deus que quer iluminar a o sentido da dignidade da pessoa humana no Texto Constitucional, é um encontro que de se dá a partir de Deus. As religiões falam sobre Deus, a espiritualidade é uma experiência a partir de Deus. É uma abertura, uma transcendência, é um abrir e jamais um fechar, daí porque a espiritualidade do sentido da pessoa humana, contido no postulado jurídico da dignidade da pessoa humana engloba todos os homens, inclusive, os não religiosos, os religiosos, os agnósticos etc, porque é conceito jurídico fundamental que transcende as religiões.

Só imbuídos de espiritualidade poderemos compreender o verdadeiro significado da dignidade da pessoa humana em nosso ordenamento jurídico. Só assim poderemos ver no homem um fim em si mesmo, independente de suas riquezas, de seus credos, de sua classe social, de estar empregado ou não empregado etc.

Desenvolver esta espiritualidade em nós, é aperfeiçoar nossa 39 BOFF, Leonardo. Espiritualidade - Um caminho de transformação. $2^{\mathrm{a}}$ ed. Rio de Janeiro: Sextante. 2001. p. 66. 
capacidade de interpretar o direito a partir de uma visão profundamente humana, só assim o direito fará sentido em nossas vidas. Se somos espiritualizados, somos mais contemplativos, somos capazes de escutar as mensagens e os valores que impregnam o mundo a nossa volta, sobretudo dos excluídos, somos capazes de nos indagar: qual o significado disso tudo para mim?

Nos tornamos mais sensíveis, e por isso evoluímos juridicamente, porque passamos a ver a temporalidade das coisas, a usura do tempo, e saber que não estamos vivos apenas porque ainda não morremos, mas porque a vida, conforme bem lembra Leonardo Boff, é uma oportunidade para crescer, para aceitar nossos defeitos, nossos limites nosso envelhecimento e nossa mortalidade. ${ }^{40}$

Mais espiritualizados, mais humanos. O Estado brasileiro é laico, quer dizer, não possui religião oficial, porém, como é fundado sob a proteção de Deus, reconhece juridicamente a espiritualidade da pessoa humana, e por conseguinte, a dignidade da pessoa humana, dignidade esta que se estrutura partir da experiência humana de Deus, enquanto espiritualidade.

Nos escritórios, nos gabinetes, onde se desenvolve o direito enquanto jogo de puro poder econômico, pode até triunfar o cinismo, o descrédito em tudo e em todos. Porém, não podemos desprezar a aurora que vem, não podemos desfazer o olhar inocente da uma criança, não podemos contemplar com indiferença a profundidade do céu estrelado sem cair no silêncio e na profunda reverência, nos perguntando o que se esconde atrás das estrelas, qual é o caminho da minha vida, o que posso esperar dela? O que é o ser humano que sou e os que me rodeiam? Para que serve o meu trabalho? Qual o sentido do meu trabalhar?. São perguntas que o ser humano sempre se coloca, e, ao colocá-las revela-se como ser espiritual, e sobretudo com dignidade, uma vez que a dignidade da pessoa humana é valor imanente a todo e qualquer homem. ${ }^{41}$

O conceito de espiritualidade humana, trabalhado neste tópico sob a ótica do Texto Constitucional e do postulado normativo da dignidade da pessoa humana - art. $1^{\circ}$, III da Constituição Federal, deve ser aplicado à luz da efetividade e concretização (princípio dá máxima efetivação) das normas constitucionais. Aliás, é o alerta que nos faz Cleber Francisco Alves ${ }^{42}$ quando $40 \quad$ Espiritualidade. Um caminho de transformação. op. cit. p. 73.

41 Cf. BOFF, Leonardo. Espiritualidade ... op. cit. p. 80/81.

42 ALVES, Cleber Francisco. O Princípio Constitucional da Dignidade da Pessoa Humana: o enfoque da Doutrina Social da Igreja. Rio de Janeiro: Renovar. 
sustenta com saber,

Vale enfatizar que essa noção de dignidade da pessoa humana - ao ingressar no mundo jurídico - não deve ser tomada num sentido meramente teórico ou abstrato, pois tal enfoque não é compatível com o tratamento mais contemporâneo que a principiologia constitucional vem merecendo, como visto anteriormente. Esse princípio, ainda que seja de pouca densidade normativa, deve ter um proeminência absoluta, presidindo todo o trabalho de interpretação e implementação efetiva das demais normas constitucionais e infraconstitucionais, podendo servir de fundamento autônomo e bastante por si só, para embasar decisões que reconhecem a inconstitucionalidade de preceitos que venham a afrontá-lo.

Para finalizar este tópico querido leitor, trazemos à colação as palavras sempre sensíveis e iluminadas, do Ministro do Supremo Tribunal Federal, Carlos Ayres Britto ${ }^{43}$, que bem se amoldam a tudo que trabalhamos neste item. Ouçamos o Ministro,

Terminemos este segmento reflexivo com a ponderação de que não desconhecemos o grande risco intelectual de quem se dispõe a falar sobre Deus, sabido e ressabido que a existência mesma de Deus nem pode ser rigorosamente confirmada nem rigorosamente desconfirmada pela Ciência. Deus, então, para os intelectuais que O admitem é sempre uma hipótese de trabalho. Um postulado. um conceito que se intui a priori, como é próprio de todo postulado. Logo, falar sobre Ele não é formular proposições deduzidas da análise de elementos objetivos que se conectam para formar

2001. p. 176/177.

43 Teoria da Constituição. Rio de Janeiro: Forense. 2003, p. 15. 
um todo unitário, mas saltar imediatamente para uma conclusão. Todavia, não foi a partir da intuição da existência de uma norma fundamental simplesmente pensada, uma norma fundamental hipotética, e, portanto, pressuposta (não efetivamente posta por nenhum órgão jurídico, nenhum costume, nenhum instância volitiva imanente, enfim), que HANS KELSEN pôde falar de uma Ciência do Direito? Uma ordem sistemática de conhecimentos que tem naquela hipotetização normativo-fundamental a sua própria condição inicial de possibilidade como esfera autônoma e científica do saber?

\subsection{Porque o ser humano é pessoa}

Continuemos a responder àquela indagação primeva, por que o ser humano possui dignidade?

Porque ele é pessoa. Só do homem dizemos que é pessoa, não dizemos do cão, do cavalo, do gato, nem mesmo das plantas e das pedras. $\mathrm{O}$ conceito do homem enquanto pessoa se afirma no ocidente a partir do "humanismo", entendido aqui como aquele amplo movimento espiritual que, no século XV, começou na Itália com alguns pensadores como Ficino, Pico della Mirandola, Valla, Maquiavel etc, que no século seguinte se expandiu por todo continente europeu.

São Tomás de Aquino é chamado de o precursor dos humanistas. O humanismo tem com suas características principais: uma concepção altamente positiva do homem e a volta à era clássica grego-romana tomada com modelo de uma cultura que teve esse alto conceito do homem. ${ }^{44}$

Por ser pessoa o homem possui dignidade. Lembremos de Kant. As coisas têm preço, possuem valor exterior (de mercado) e manifestam interesses particulares. A dignidade representa um valor interior (moral) e é de interesse geral. A dignidade enquanto valor moral é incomensurável, por não ser mercadoria não pode ser substituído por outro, como soí acontecer no caso das coisas.

Ademais, o homem como valor absoluto dotado de dignidade não 44 MONDIN, Battista. O Humanismo Filosófico de Tomás de Aquino.

Bauru: EDUSC. 1998. p. 7 
pode dispor de si mesmo, pelo mesmo raciocínio anterior, ou seja, por não ser coisa. O homem não é "propriedade" de si mesmo. Na medida em que ele é pessoa, ele é o sujeito ao qual pode caber a propriedade de coisas. Ora, se ele fosse propriedade de si mesmo, seria ele uma coisa, cuja posse poderia reivindicar, pura aporia.

Ele é, insista-se, pessoa, o que é diferente de propriedade e, portanto, não é uma coisa, pois é impossível ser, ao mesmo tempo, coisa e pessoa, daí porque o homem não pode dispor de si mesmo, não pode instrumentalizarse. $^{45}$

Segundo Battista Mondin, o homem é um ser cultural, espiritual e livre, mas é sobretudo pessoa e um valor absoluto.

É cultural, na medida em que não é como as plantas e os animais, puro produto da natureza; mas o é fruto de uma sapiente colaboração entre natureza e cultura. A cultura não é uma roupa que se vista ou se dispa ao próprio prazer, não é qualquer coisa acidental ou secundária, mas é um elemento constitutivo da essência do homem, ela faz parte da natureza humana. Sem a cultura não é possível existir nem a pessoa individualmente, nem o grupo social. ${ }^{46}$

É espiritual na medida em que possui a capacidade de transcender a si próprio, somente o espírito é livre, porque sopra onde quer. É livre porque dotado de autonomia e vontade iluminadas pela razão, não está subordinado aos instintos como estão os animais. É pessoa e valor absoluto porque não é um valor instrumental, ele pertence à ordem dos fins, e não à dos meios.

Agora, o valor absoluto do homem está no espírito. Se não se situa (o valor) no espírito é, totalmente gratuito e arbitrário considerar o homem um valor absoluto. Se o homem é só corpo, só matéria, ele se torna necessariamente uma realidade manipulada, instrumentalizada e, portanto, não pode ter um valor absoluto. O homem é absoluto e infinito enquanto valor, ainda que finito como ser. ${ }^{47}$

Ninguém melhor do que Miguel Reale, estudou a fundo as questões

45 MORAES, Maria Celina Bodin de. O Conceito de Dignidade Humana: substrato axiológico e conteúdo normativo. In Constituição, Direitos Fundamentais e Direito Privado. $2^{\mathrm{a}}$ ed. Porto Alegre: Livraria do Advogado. 2006. p. 115, e p. 135 , nota de rodapé $n^{\circ} 96$.

46 Cf. MONDIN, Battista. Definição Filosófica da Pessoa Humana. op. cit. 15.

47 Cf. MONDIN, Battista. Definição Filosófica da Pessoa Humana. op. cit. p. 44. 
filosóficas que envolvem o homem, articulado com o mundo jurídico. São dele, as palavras que seguem,

O homem, considerado na sua objetividade espiritual, enquanto ser que só se realiza no sentido de seu dever ser, é o que chamamos de pessoa. Só o homem possui a dignidade originária de ser enquanto deve ser, pondo-se essencialmente como razão determinante do processo histórico. ${ }^{48}$

Malgrado o valor absoluto de todo ser humano, infelizmente, como pontua a Ministra do Supremo Tribunal Federal, Cármen Lúcia Antunes Rocha $^{49}$, ainda convivemos com subomens empilhados sob viadutos, crianças feito pardais de praça, sem pouso nem ninho certos, velhos purgados da convivência das famílias, desempregados amargurados pelo seu desperdício humano, deficientes atropelados em seu olhar sob as calçadas, presos animalados em gaiolas sem porta, enfim, exclusões sociais de todos os tipos e espécies que ferem mortalmente o princípio da dignidade da pessoa humana.

Ainda fortes no pensamento da Ministra Cármen Lúcia Antunes Rocha $^{50}$, podemos afirmar que,

Toda pessoa humana é digna. Essa singularidade fundamental e insubstituível é ínsita à condição humana, qualifica-o nessa categoria e o põe acima de qualquer indagação. Quando se questiona, nestes chamados tempos modernos, se há de permitir, ou não o nascimento de um feto no qual se detecte a existência de anomalia a impossibilitálo para uma vida autônoma, está-se a infirmar aquela assertiva e a tornar a humanidade um meio para a produção de resultados e a desconhecer ou desprezar a condição do homem de ser que é fim em si mesmo e digno pela própria natureza. Aquilo

48 REALE, Miguel. Filosofia do Direito. 17 ed. São Paulo: Saraiva. 1996. p. 220.

49 O Princípio da Dignidade da Pessoa Humana e a Exclusão Social. op. cit. p. 25.

50 O Princípio da Dignidade da Pessoa Humana... op. cit. p. 28. 
traduz-se, pois, como injustiça contra os que não se apresentam em iguais condições psicofisiológicas, intelectuais etc. É a injustiça havida na indignidade revelada na desumanidade do tratamento dedicado ao outro. É a injustiça do utilitarismo que se serve do homem e o dota de preço segundo a sua condição peculiar, que se expressa numa forma em vez de se valer pela essência humana de que se dota.

Ser pessoa é uma realização em direção ao outro. A realização de nós mesmos passa necessariamente pelo próximo. Por este motivo, para definir adequadamente a pessoa, não basta a subsistência e nem a coexistência com os outros, é necessária também a proexistência, que é o preocupar-se ativamente com o destino do outro. A proexistência que ajuda a realização dos outros (do próximo) repercute positivamente na pessoa do próprio proexistente, é como que se antecipasse uma via para a realização de sua pessoa: consolida-a, enriquece-a, torna-a maior, mais nobre, mais feliz. ${ }^{51}$

Por fim, fechamos este item com as palavras insuperáveis da Ministra do Supremo Tribunal Federal, Cármen Lúcia Antunes Rocha, que com fina sensibilidade verberou,

A dignidade da pessoa humana é a prova de que o homem é um ser de razão compelido ao outro pelo sentimento, o de fraternidade, o qual, se às vezes se ensaia solapar pelo interesse de um ou outro ganho, nem por isso destrói a certeza de que o centro de tudo ainda é a esperança de que a transcendência do homem faz-se no coração de outro, e nunca na inteligência aprisionada no vislumbre do próprio espelho. Afinal, mesmo de ouro que seja o espelho, só cabe a imagem isolada. Já no coração, ah! coração, cabe tudo.

6. Referências Bibliográficas 
ALVES, Cleber Francisco Alves. O Princípio Constitucional da Dignidade da Pessoa Humana: o enfoque da Doutrina Social da Igreja. Rio de Janeiro: Renovar. 2001.

ALVES, J.A. Lindgren. Os Direitos Humanos como tema global. São Paulo: Perspectiva. 1994.

ÁVILA, Humberto. Princípios e Regras e a Segurança Jurídica. Revista de Direito do Estado - RDE. Rio de Janeiro: Renovar. $n^{\circ}$ 1, janeiro/março de 2006.

ÁVILA, Humberto. Teoria dos Princípios. da definição à aplicação dos princípios jurídicos. 2 ed. São Paulo: Malheiros. 2003.

BARCELlOS, Ana Paula de. A Eficácia Jurídica dos Princípios Constitucionais. O Princípio da Dignidade da Pessoa Humana. Rio de Janeiro: Renovar. 2002.

BARROSO, Luís Roberto (org.). A Nova interpretação Constitucional. Ponderação, Direitos Fundamentais e Relações Privadas. 2 ed. Rio de Janeiro: Renovar. 2006

BOFF, Leonardo. Águia e a galinha: uma metáfora da condição humana. 24 ed. Petrópolis: Vozes. 1998.

BOFF, Leonardo. Espiritualidade - Um caminho de transformação. 2 ed. Rio de Janeiro: Sextante. 2001..

BRITTO, Carlos Ayres de.. Teoria da Constituição. Rio de Janeiro: Forense. 2003.

DALAI LAMA. Sua Santidade o Dalai Lama. Um Ética para o Novo Milênio. 7 ed. Rio de Janeiro: Sextante. 1999.

DICIONÁRIO DE FILOSOFIA NICOLAABBAGNANO. São Paulo: Martins Fontes. 1998. p. 276.

JERÔNIMO, Patrícia. Os Direitos do Homem à escala das civilizações Proposta de análise a partir do confronto dos modelos ocidental e islâmico. 
Coimbra: Almedina. 2001.

JOÃO PAULO II. Carta Encíclica Fides et Ratio. Aos Bispos da Igreja Católica sobre as relações entre a Fé e a Razão. 7 ed. São Paulo: Paulinas. 2004.

LAFER, Celso. A Reconstrução dos Direitos Humanos: um diálogo com o pensamento deHanna Aredent. São Paulo: Cia das Letras, 1988.

LENZA, Pedro. Direito Constitucional Esquematizado. $10^{\mathrm{a}}$ ed. São Paulo: Método. 2006.

MONDIN, Battista. Definição Filosófica da Pessoa Humana. Bauru: EDUSC. 1998.

MONDIN, Battista. O Humanismo Filosófico de Tomás de Aquino. Bauru: EDUSC. 1998.

MORAES, Alexandre de. Direito Constitucional. 19 ed. São Paulo: Atlas. 2006. p. 15.

MORAES, Maria Celina Bodin de. O Conceito de Dignidade Humana: substrato axiológico e conteúdo normativo. In: Constituição, Direitos Fundamentais e Direito Privado. 2 ed. Porto Alegre: Livraria do Advogado. 2006.

NOGUEIRA, Roberto Wagner Lima Fundamentos do Dever Tributário. Belo Horizonte: Del Rey. 2003.

REALE, Miguel. Filosofia do Direito. 17 ed. São Paulo: Saraiva. 1996.

ROCHA, Carmem Lúcia Antunes O Princípio da Dignidade da Pessoa Humana e a Exclusão Social. Revista Interesse Público. São Paulo. Ano 1. no 4 , outubro/dezembro de 1999.

SARLET, Ingo Wolfganf. Dignidade da Pessoa Humana e Direitos Fundamentais na Constituição Federal de 1988. 4 ed. Porto Alegre: Livraria do Advogado. 2006, p. 42. 
SILVA, Deonísio da De onde vêm as palavras - origens e curiosidades da língua portuguesa. 14 $4^{\mathrm{a}}$ ed. São Paulo: A Girafa. 2004.

TELLES JÚNIOR, Goffredo. O direito quântico. 6 ed. São Paulo: Max Limonad. 1985,

VILANOVA, Lourival. Sobre o Conceito de Direito. Escritos Jurídicos e Filosóficos. São Paulo, v. 1. 2003, p. 14. 